\title{
Optimal Service Planning in a Temporary City
}

\author{
Muteb Alotaibi, Graham Clarke, Nick Malleson \\ University of Leeds, Leeds, UK \\ Email: ml11mka@leeds.ac.uk, G.P.Clarke@leeds.ac.uk, N.S.Malleson@leeds.ac.uk
}

How to cite this paper: Alotaibi, M., Clarke, G., \& Malleson, N. (2020). Optimal Service Planning in a Temporary City. Journal of Service Science and Management, 13, 709728.

https://doi.org/10.4236/jssm.2020.135045

Received: July 29, 2020

Accepted: October 9, 2020

Published: October 12, 2020

Copyright $\odot 2020$ by author(s) and Scientific Research Publishing Inc. This work is licensed under the Creative Commons Attribution International License (CC BY 4.0).

http://creativecommons.org/licenses/by/4.0/ (c) (i) Open Access

\begin{abstract}
Temporary cities provide unique challenges in terms of urban planning and management. In particular, there are problems in terms of providing adequate service provision and ensuring an equitable access to those services. In addition, when temporary cities also involve a mass gathering for an event, there is a need for a strategic plan for managing the movement of this crowd over time. The Hajj is an annual religious event which hosts about 3 million pilgrims each year. It is the second largest annual gathering of Muslims in the world. The pilgrims reside for a number of days in the "tent city" of Mina. The organisers of the Hajj must plan the location of services to support this huge temporary population and also provide a plan to facilitate the performing of the religious rituals in an easy and safe manner (in particular to avoid overcrowding). In this paper, we estimate and map the distribution of populations across Mina during the Hajj and explore the location of existing services to investigate how well served the population is within various parts of the City. For illustrative purposes, we explore access to health centres and civil defence (mainly fire services). After analysing the current provision of these services across the City (through building suitable accessibility measures) we use a location allocation model to compare the current provision with a set of optimal, model-based locations. The model is also used to operationalise a series of what-if scenarios including reducing the number of facilities in line with increased Government concerns over escalating costs and changing demand in line with pilgrim movements throughout the day. The results of the location-allocation modelling could also help revamp staffing rotas-not only can the model provide optimal locations they can estimate the workloads associated with each facility location (based on the volume of local demand), meaning the thousands of health workers could be also located more optimally.
\end{abstract}

\section{Keywords}

Location-Allocation Modelling, The Hajj, Service Analysis, Temporary City 


\section{Introduction}

The use of urban space by persons on a temporary basis provides unique problems for planners and administrators. Temporary urban spaces may most often include sites for festivals, exhibitions and major sporting events. However, in some rarer cases entire cities might be seen as temporary. One example of the latter is the Hajj for Muslims, described as the largest gathering of people to take place on an annual basis. The Hajj, in the city of Mina in the eastern district of Makkah City in Saudi Arabia, takes place over a period of just 6 days but has to accommodate approximately 2.5 million pilgrims in a so-called tented city. To cater for that many people the city extends over $20 \mathrm{sq} \cdot \mathrm{km}$. Pilgrims can be both local and international and need many of the services that would be expected in a permanent city of that size. The increasing number of pilgrims who visit each year, coupled with the fact that space in Mina is limited, means that decisionmakers need to ensure that the current services (such as health, security, fire, etc.) are located optimally with respect to the population that needs to be accommodated. Further, if the planners decide to decrease the number of services to reduce costs, what are the subsequent optimum locations for this reduced number of services? In addition it is important to study the dynamics of locations; the locations of tents only capture the locations where pilgrims sleep. It is during the pilgrim's movement towards Jamarat to participate in the religious rituals that the expected demand for services is likely to peak. So it is important to estimate the optimum locations of services at different times of the day, something rarely done in location studies. Hence this paper is motivated by a need for a better understanding about where Hajj services should be located to best serve the transient population. The novel contribution of the paper is that it can provide decision makers with information on the best locations to provide services, at different times of the day and for different potential cost models.

The aim of this paper is to examine the existing provision of services in Mina during the Hajj and to measure how accessible these services are to the visiting population. This will be explored using accessibility scores within a geographical information system (GIS) environment. Then we use a suite of location-allocation models (LAMs) to optimally locate those services and compare those optimal distributions with the present distributions. This will be followed by the analysis of two scenarios that explore changes in service supply and demand. First, we examine a scenario for change based around reducing supply-side costs which is a core aim of the Saudi Government looking forward. According to Vision 2030 objectives, (Vision, 2019), the Government is seeking to raise the efficiency of the services they offer by cutting costs. To facilitate this requirement, we analyse the optimal locations of a reduced set of service facilities. In terms of demand, our second scenario introduces the notion of service provision by time of dayto do that we follow the movement of the pilgrims over a 24 hour period and suggest that some of the service locations should be available only at certain times of the day. There are few examples of LAMs being used in this way in the 
literature to date.

The rest of the paper is structured as follows. In Section 2, we review the literature on temporary cities and give more details about the Hajj at Mina. In Section 3, we examine the present distribution of services and measure zonal accessibility. In Section 4, we introduce the location-allocation models and discuss the optimal location of key services compared to existing locations. Further, In Section 4, we provide the two what-if scenarios. In Section 5, we discuss some results of the analysis. Finally, we offer some conclusions and policy recommendations in Section 6.

\section{Temporary Cities and the Hajj}

The temporary city (or temporary use of urban spaces) has been growing in importance in recent years within the literature of urban geography/studies. For a number of authors the temporary city refers to how spaces vary in use over time across a city. It might thus refer to how the public and/or private sector uses derelict or abandoned spaces within cities for temporary exhibitions, festivals, entertainment events, or religious festivals (Haydn \& Temel 2006; Madanipour, 2018). Houdart (2012), for example, depicts the Shanghai Expo as a good example of a temporary city of this format. These large-scale events can become part of important city marketing campaigns and are often viewed positively by city authorities. However, other studies show temporary usage in more negative termsas a response to the inability of a property (or set of properties) to meet its original need and thus property owners looking to obtain some short term financial return. This is illustrated by the emergence of temporary land uses such as car parks, storage areas or scrap yards. In these examples temporary use is thus considered to signify a time of crisis in the city. Indeed, the cost of creating and establishing temporary open spaces is often significantly less than the value they create for their users (Mady, 2012). Ferreri (2015) labels this form of temporary city as "low-budget urbanism".

Some view the temporary use of spaces in cities with a more positive outlook. For some, vacant land in cities has provided an opportunity for the "creative class" to engage with new forms of urban entertainment. Colomb (2012) for example, discusses the innovations in land-use within derelict areas of Berlin. $\mathrm{He}$ notes over 100 new land-use types developing in these spaces including niche music venues, beach bars and community gardens bringing these spaces back to life. Of course some of these become permanent very quickly and there is always tensions with land owners who eventually wish to see more lucrative developments on their land. In that sense it is important to consider this form of temporary land-use alongside debates over wider urban processes and structural dynamics of political, economic and cultural change (Madanipour, 2018).

In some cities temporary land-use change can be seen on a larger scale, especially in times of economic hardship. One particular manifestation of such a temporary city is the so-called tent city, that might emerge as a consequence of housing crises. Loftus-Farren (2011), Herring \& Lutz (2015) and Sparks (2017) 
discuss some of the so-called tent cities which have emerged in derelict areas of US cities as homelessness has increased in recent years. Some scholars view these cities as a kind of innovation, while others are critical of governments who seem incapable of affording the homeless a good, living home. In many instances the concern is that these temporary spaces become more permanent, as is the case with many shanty towns around the world which began as sites of temporary accommodation.

Tent cities is also the name applied to temporary cities built for many pilgrimage sites. In this case these are constructed to house pilgrims rather than the homeless and facilities thus need to be in place for "paying guests". However, planning a large-scale temporary city to create a sense of place from scratch, whilst also providing all the necessary services, is not an easy task. The operation involves combining knowledge, skill and judgement and an understanding of how successful places work and why some developments fail (Montgomery, 1998). There are many historical examples of planning permanent cities from scratch that might be useful for planning a modern temporary city. In the UK in the c19th new towns were often built by industrial magnets who wanted to provide better accommodation and service provision for their workforce to allow them to escape from slum conditions elsewhere. Examples in the UK include Saltaire, Bourneville, New Lanark and Port Sunlight. Outside the UK good examples include Chandigarh in India, Canberra in Australia and Pullman in the USA. For a good summary of this literature see Garner (1992).

Given that background we now go into more detail about the temporary city constructed for the Hajj. The Hajj pilgrimage is one of the five pillars of the Islamic religion (faith, prayer, fasting, charity and Hajj). Most Muslims who are capable in terms of physical and economic means are obligated (by their faith) to perform the Hajj at least once in their lives. The history and development of the Hajj are discussed by King (1972), Peters (1996) and Al-Kodmany (2009). Figure 1 shows the location of Mina, the temporary city, in relation to the municipality of Mashaer/Makkah as a whole. The event takes place over 6 days starting on the 8th day of the last month of the Hijri calendar. On the morning of the 8th, pilgrims move to Mina and stay there during the entire festival. After undertaking prayers at both Arafat and Muzdalefah they return to Mina for the throwing of 21 stones from the Jamarat Bridge in Mina (symbolizing the throwing of stones at the devil). In early 2007, construction began on a new Jamarat Bridge (see Figure 2) which was completed in 2010. The old pillars of the former bridge have been replaced by larger elliptical-shaped pillars. It currently has 5 levels with a potential capacity to increase to 12 stories and accommodate 5 million pilgrims if needed. The maximum capacity of every tier of the bridge is 125,000 pilgrims per hour.

The pilgrims are accommodated in tents throughout the region, but mostly in Mina. Each camp is fitted out with bathrooms, kitchen and ablution facilities. Further, every camp is colour-coded and that space is allocated to different ethnic groups: pilgrims are issued with badges with their colour and number to 


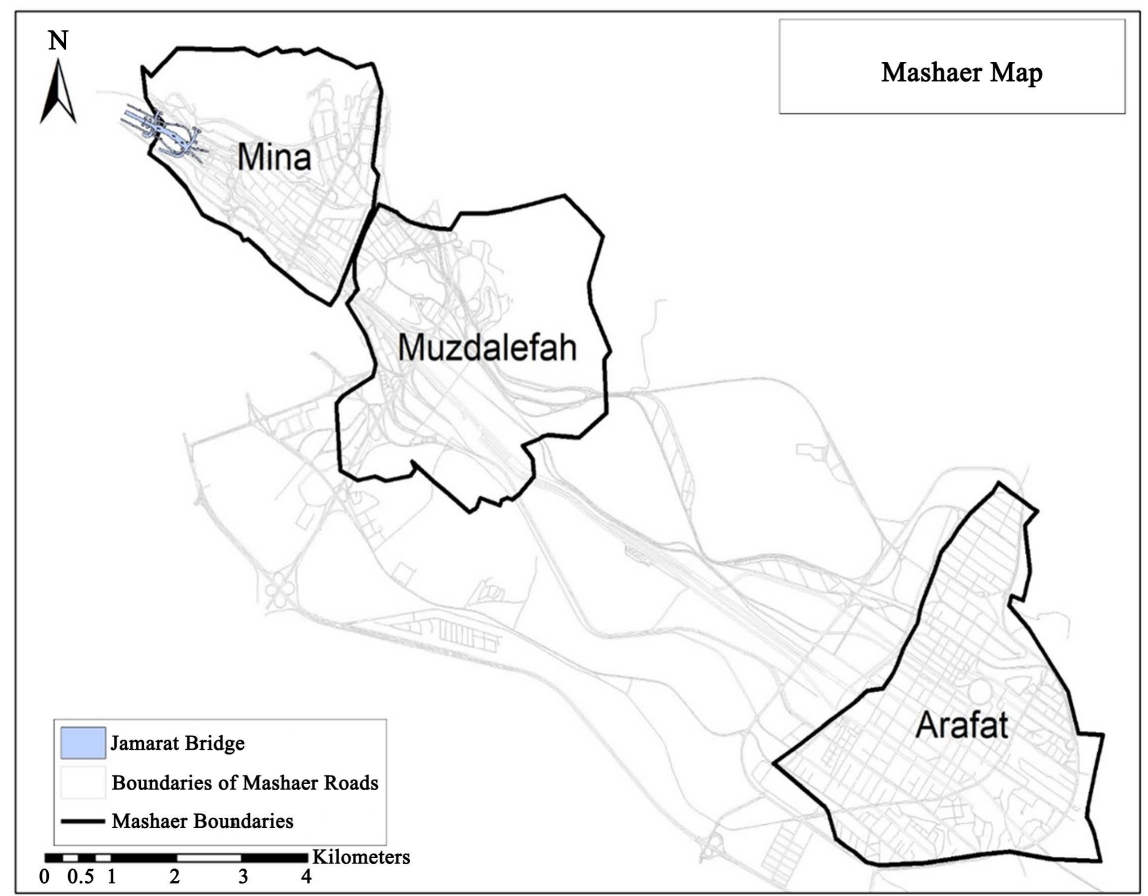

Figure 1. Mina, Muzdalefah and Arafat locations (the municipality of Makkah).

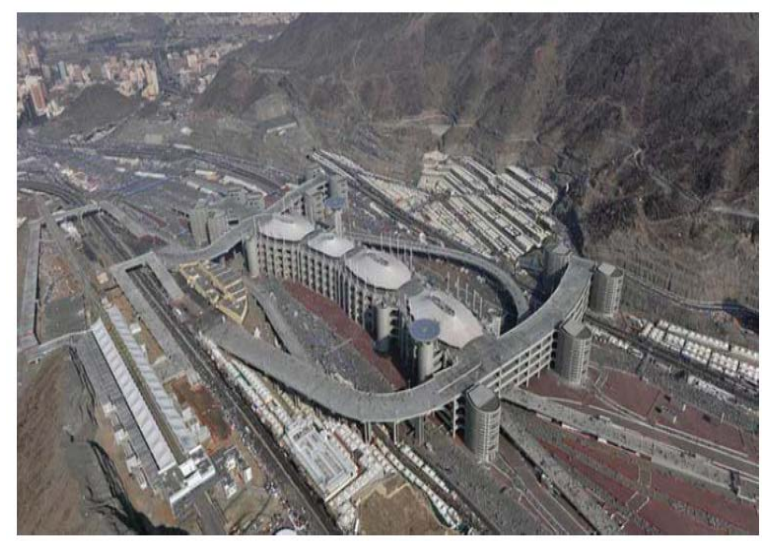

Figure 2. The new multi-storey Jamarat Bridge, which was completed in 2010 (Al-Kodmany, 2013).

guide them if they become lost. For the rest of the year, Mina remains almost deserted, similar to other holy places such as Muzdalifah and Arafat, as the tents are folded away and stored after the event. Figure 3 shows the extent of the tented city.

Table 1 gives statistics on the number of pilgrims from 1995 to 2019. It can be said that with swifter and cheaper transport, more and more Muslims have been able to travel to Makkah for the Hajj. The numbers did dip around 2013 however when various scares around flu epidemics temporarily reduced the numbers attending. They also dipped significantly in 2020 as a result of the COVID-19 pandemic, when the Government restricted the pilgrimage to citizens inside the country. 


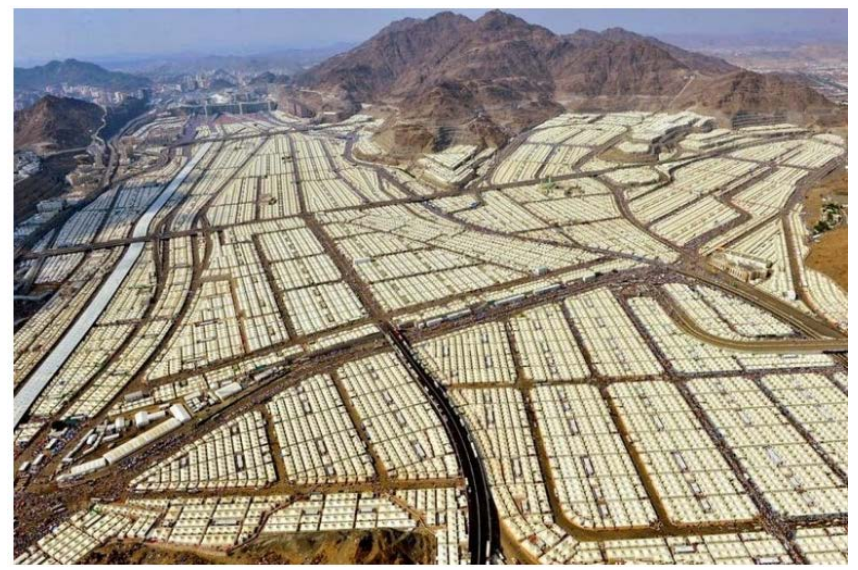

Figure 3. The tented city at mina.

Table 1. The number of pilgrims at the Hajj over time.

\begin{tabular}{|c|c|c|c|}
\hline Year & From Inside The Kingdom & From Outside The Kingdom & Total \\
\hline 1995 & 784,769 & $1,080,465$ & $1,865,234$ \\
\hline 1996 & 774,260 & $1,168,591$ & $1,942,851$ \\
\hline 1997 & 699,770 & $1,132,344$ & $1,832,114$ \\
\hline 1998 & 775,268 & $1,056,730$ & $1,831,998$ \\
\hline 1999 & 571,599 & $1,267,555$ & $1,839,154$ \\
\hline 2000 & 549,271 & $1,363,992$ & $1,913,263$ \\
\hline 2001 & 590,576 & $1,354,184$ & $1,944,760$ \\
\hline 2002 & 610,117 & $1,431,012$ & $2,041,129$ \\
\hline 2003 & 592,368 & $1,419,706$ & $2,012,074$ \\
\hline 2004 & 629,710 & $1,534,769$ & $2,164,479$ \\
\hline 2005 & 700,603 & $1,557,447$ & $2,258,050$ \\
\hline 2006 & 724,229 & $1,654,407$ & $2,378,636$ \\
\hline 2007 & 746,511 & $1,707,814$ & $2,454,325$ \\
\hline 2008 & 679,008 & $1,729,841$ & $2,408,849$ \\
\hline 2009 & 699,313 & $1,613,965$ & $2,313,278$ \\
\hline 2010 & 989,798 & $1,799,601$ & $2,789,399$ \\
\hline 2011 & $1,099,522$ & $1,828,195$ & $2,927,717$ \\
\hline 2012 & $1,408,641$ & $1,752,932$ & $3,161,573$ \\
\hline 2013 & 600,718 & $1,379,531$ & $1,980,249$ \\
\hline 2014 & 696,185 & $1,389,053$ & $2,085,238$ \\
\hline 2015 & 567,876 & $1,384,941$ & $1,952,817$ \\
\hline 2016 & 537,537 & $1,325,372$ & $1,862,909$ \\
\hline 2017 & 600,108 & $1,752,014$ & $2,352,122$ \\
\hline 2018 & 612,953 & $1,758,722$ & $2,371,675$ \\
\hline 2019 & 634,379 & $1,855,027$ & $2,489,406$ \\
\hline
\end{tabular}


The planning of services, and concerns over safety, have been ongoing concerns. There have been many disasters in the city, as outlined in Table 2, which have heightened the need for better protection and care. Accordingly, the major concern of decision makers is how pilgrims can perform their rituals without danger or threat to life. This means providing health facilities, security forces, civil defences, qualified personnel, logistics and materials to serve the pilgrims who come to perform the Hajj (Eltahir, 2000).

Some aspects of the operation of the Hajj have been covered to date in the literature. The historical and religious significance of the Hajj appear in a number of key studies (King, 1972; Peters, 1996; Bozonelos, 2015). Matters around congestion, crowd management and the movement of people over the 6 days have also been addressed (Koshak, 2006; Al-Kodmany, 2009; Fayoumi et al., 2011; Al-Kodmany, 2013; Haase et al., 2018). Studies dealing with services are more limited; although see Ahmed et al. (2006) and in relation to health issues. Halabi (2012), Mitchell, Rashid et al. (2013), used a combined approach (navigation systems, people tracking and location-based systems) to aid pilgrim movements at the Hajj by providing an ability to locate family and friends and important places within Mina. Similarly, Alharthi \& Gutub (2017) focused on tracking where specific pilgrims, by nationality, travel to within the tented city to understand more about the flow of people during the Hajj. However, no studies have examined service location optimisation as a process to ensure that services are well distributed based on pilgrims needs during their residency and movement to do their ritual easily and safely.

Table 2. Hajj fatalities in mina.

\begin{tabular}{|c|c|c|}
\hline Reason & Event & Location \\
\hline Stampede & $\begin{array}{l}\text { July 2, 1990: A stampede inside a pedestrian tunnel } \\
\text { leading out from Makkah towards Mina and the } \\
\text { Plains of Arafat led to the deaths of } 1426 \text { pilgrims. }\end{array}$ & $\begin{array}{l}\text { Almaaisim Tunnel } \\
\text { (Mina) }\end{array}$ \\
\hline Stampede & $\begin{array}{l}\text { May 23, 1994: A stampede killed at least } 270 \text { pilgrims } \\
\text { at the stoning ritual (BBC, 2007). }\end{array}$ & $\begin{array}{l}\text { Jamarat Bridge } \\
\text { (Mina) }\end{array}$ \\
\hline Fire & $\begin{array}{l}\text { April 15, 1997: There were } 343 \text { deaths and more } \\
\text { than } 1500 \text { estimated casualties in the tented city } \\
\text { (Ahmed et al., 2006). }\end{array}$ & $\begin{array}{l}\text { Tented City } \\
\text { (Mina) }\end{array}$ \\
\hline Stampede & $\begin{array}{l}\text { April 9, 1998: } 118 \text { pilgrims were trampled to death } \\
\text { and } 180 \text { injured in a crushing incident (BBC, 1998). }\end{array}$ & $\begin{array}{l}\text { Jamarat Bridge } \\
\text { (Mina) }\end{array}$ \\
\hline $\begin{array}{l}\text { Trampling } \\
\text { to death }\end{array}$ & $\begin{array}{l}\text { March 5,2001: } 35 \text { pilgrims were trampled to death } \\
\text { in a stampede during the stoning ritual (BBC, 2001) }\end{array}$ & $\begin{array}{l}\text { Jamarat Bridge } \\
\text { (Mina) }\end{array}$ \\
\hline Stampede & $\begin{array}{l}\text { February 1, 2004: } 251 \text { pilgrims were killed and } \\
\text { another } 244 \text { injured in a stampede during the } \\
\text { stoning ritual in Mina. }\end{array}$ & $\begin{array}{l}\text { Jamarat Bridge } \\
\text { (Mina) }\end{array}$ \\
\hline Stampede & $\begin{array}{l}\text { January 12, 2006: A stampede during the ritual } \\
\text { Ramy al-jamarāt on the last day of the Hajj in } \\
\text { Mina killed } 345 \text { pilgrims and injured } 1000 .\end{array}$ & $\begin{array}{l}\text { Jamarat Bridge } \\
\text { (Mina) }\end{array}$ \\
\hline $\begin{array}{l}\text { Crush due to } \\
\text { pedestrian collision }\end{array}$ & $\begin{array}{l}\text { September 2015: } 717 \text { killed and many injured in a } \\
\text { crush outside Makkah. }\end{array}$ & Road 204 (Mina) \\
\hline
\end{tabular}




\section{Current Major Service Provision in Mina versus Optimal Locations}

In this section we explore the spatial distribution of two key service activities: health centres and "civil defence" centres (of which the prime activity is the fire service). First, however, it is important to look at the demand surface for Mina as a whole during the Hajj. Based on the census data obtained from Ministry of the Hajj for 2019, the distribution of pilgrims is as shown in Figure 4. Data obtained give the total population of the whole region dedicated to a certain nationality. For more accurate analysis, the whole number of population for every nationality is divided into the number of areas belonging to that region. For example, if the whole population is 100,000 people and the areas are 10 that mean every area has 10,000 pilgrims assigned to the demand point representing that area as shown in Figure 4.

The spatial distribution of the different nationalities shown in Figure 4 is interesting in its own right. The central areas are reserved for local Arab communities whilst more peripheral areas are allocated to pilgrims from Africa and Europe. The areas marked "unknown" tend to be allocated to the workers in the city rather than the pilgrims and are located at the very edges of the city. Figure 5 shows the current location of the 23 health centres, whilst Figure 6 shows the 43 civil defence centres. The figures and corresponding tables also show how far people on average travel to the facilities from each demand origin zone.

Figure 5 and Figure 6 map how well served the different areas of Mina are in terms of access to health centres and civil defence respectively. The number of pilgrims in each distance band is shown in columns 2 and 3 of Table 3 . Thus 210,081 pilgrims currently live within $150 \mathrm{~m}$ of a health centre. These distance bands were calculated using Arc GIS.

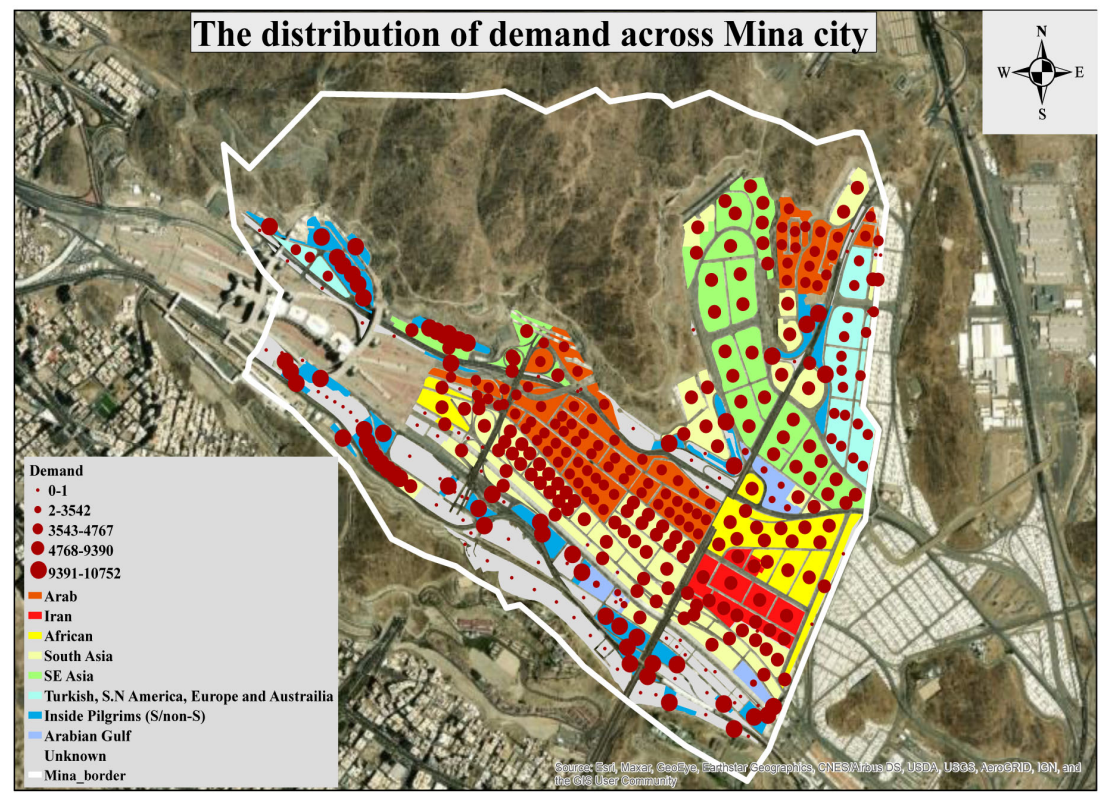

Figure 4. The distribution of demand (population) across mina city. 


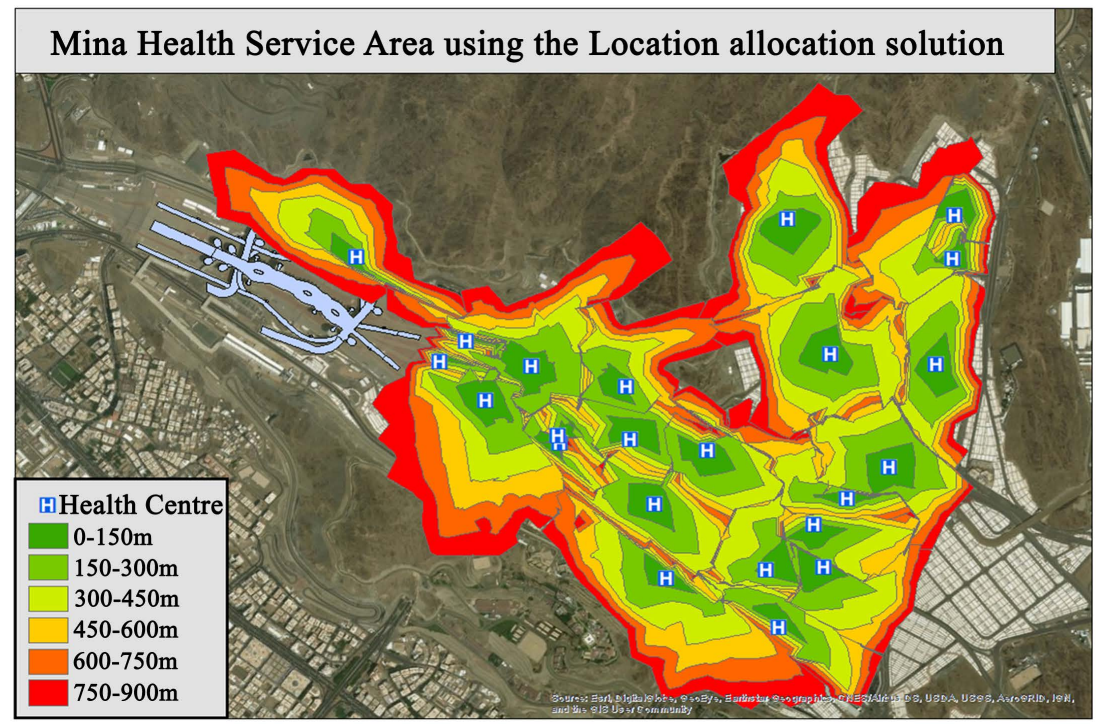

Figure 5. Distance travelled to current health service centres.

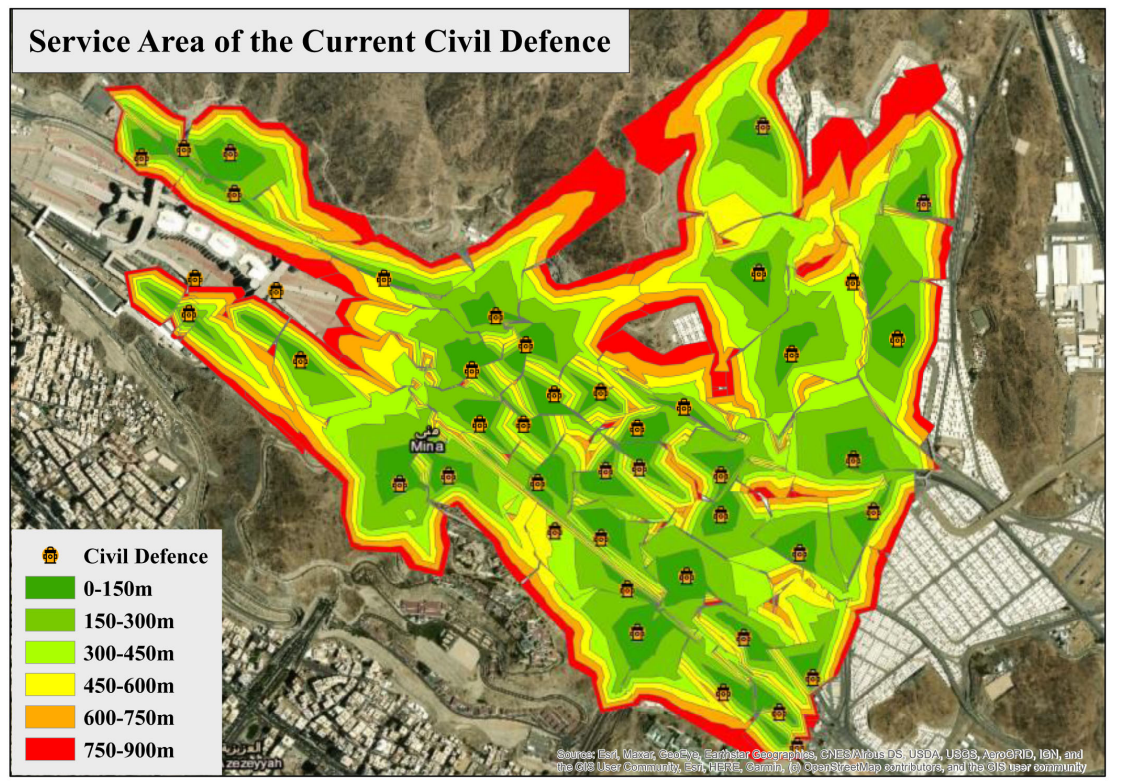

Figure 6. Distance travelled by residents to current civil defence centres.

Table 3. Numbers of pilgrims in each accessibility band.

\begin{tabular}{ccc}
\hline Distance & POP/current health centres & POP/current civil defence centres \\
\hline $\mathbf{0}-\mathbf{1 5 0} \mathrm{m}$ & 210,081 & 316,858 \\
$\mathbf{1 5 0}-\mathbf{3 0 0 \mathrm { m }}$ & 516,389 & 688,048 \\
$\mathbf{3 0 0}-\mathbf{4 5 0} \mathrm{m}$ & 705,765 & 510,906 \\
$\mathbf{4 5 0}-\mathbf{6 0 0 \mathrm { m }}$ & 479,958 & 563,961 \\
$\mathbf{6 0 0}-\mathbf{7 5 0} \mathrm{m}$ & 175,660 & 260,630 \\
$\mathbf{7 5 0}-\mathbf{9 0 0} \mathbf{m}$ & 231,183 & 111,915 \\
$\mathbf{9 0 0} \mathbf{m}+$ & 170,379 & 37,097 \\
Total population & $2,489,415$ & $2,489,415$ \\
\hline
\end{tabular}


In order to look at the optimal location of these facilities we now build a suite of location-allocation models (LAMs). Goodchild (1984) defines a LAM as the simultaneous location of central facilities and the allocation of services based upon the dispersed demand for them. LAMs provides planners with solutions to service accessibility problems by comparing the quality of previous locational decisions and proposing options for the improvement of existing systems (Rahman \& Smith, 2000). This optimisation is conducted to improve the efficiency of the whole system or improve the allocation of resources (Marianov \& de la Figuera, 2004). For this reason, it is considered a powerful and efficient technique for developing location strategies (Keane \& Ward, 2002). There are two different aims of LAM optimisation, which relate to the private and public sectors. For the former, it aims to maximise profit and market share, whilst for the latter it aims to generalise service locations to ensure equity amongst recipients, low cost and maximum efficiency (Marianov \& de la Figuera, 2004). The locations determined by LAMs are designed to be the optimum amongst other choices of services (Hodgson, 1978). LAMs rely on factors such as travel time and distance to sites where demand exists (for more technical details see Toregas et al., 1971; Birkin et al., 1996; Keane \& Ward, 2002; Farahani et al., 2012; Chen et al., 2017).

There are many different algorithms that can be used to create LAMs, such as minimise impedance, maximise coverage, maximise capacitated coverage, minimise facilities, maximise attendance, maximise market share and target market share. The minimise impedance has been most widely used for the allocation of public services (Rahman \& Smith, 2000). This function minimises the distance travelled between the demand and the facility and is the most useful in this study. Within this class of LAM, the p-median is the most utilised in the literature.

The objective function for the p-median problem can be written as follows:

$$
\text { minimise } Z=\sum_{i \in I} \sum_{j \in J} a_{i} d_{i j} x_{i j}
$$

Subject to the following constraints:

All individuals are assigned to a facility $\sum_{j \in J} x_{i j}=1$ for all $i$.

Demand must be assigned to an open facility $x_{i j} \leq \sum x_{i j}$ for all $(i, j)$.

Exact $p$ facilities have to be located: $\sum_{j \in J} x_{j j}=p$.

All demand from an individual site of demand is assigned to only one facility.

$$
x_{i j}=(0,1) \text { for all }(i, j)
$$

In this equation, $z$ represents the objective function; $I$ is the set of demand areas and the subscript $i$ is an index denoting a particular demand area; $J$ is the set of candidate facility sites and the subscript $j$ is an index denoting a particular facility site; $a_{i}$ is the number of people at demand site $i ; d_{i j}$ is the distance (time or cost of travel) separating place $i$ from candidate facility site $j ; x_{i j}$ is 1 if demand at place $i$ is assigned to a facility opened at site $j$ or 0 if demand at place $\mathrm{i}$ is not assigned to that site; $p$ is the number of facilities to be located.

LAMs provide planners with solutions to service accessibility problems. Using 
these techniques it is possible to compare the quality of previous locational decisions with optimal solutions which can improve the allocation of resources (Rahman \& Smith, 2000). For this reason, LAMs are considered a powerful and efficient technique for developing location strategies and have been used for location health, fire and emergency services in the past (Hodgson, 1978; Rahman \& Smith, 2000; Keane \& Ward, 2002; Kar \& Hodgson, 2008).

Figure 7 shows the optimal locations for 23 health centres as produced by the LAM alongside the actual current 23 locations. The spider plots shows the residential or demand zones allocated to each optimal centre. Many are in the same areas of the city but the optimal solution shows 9 or 10 centres now in completely new areas of Mina. LAMs always tend to provide a more dispersed pattern than seen in reality as they try to distribute facilities more equitably. Thus, the LAM has a tendency to improve access for those residents at the periphery of the city compared to the location of the current centres. The resultant increase in accessibility can be seen in Table 4 which shows the improvement in the number

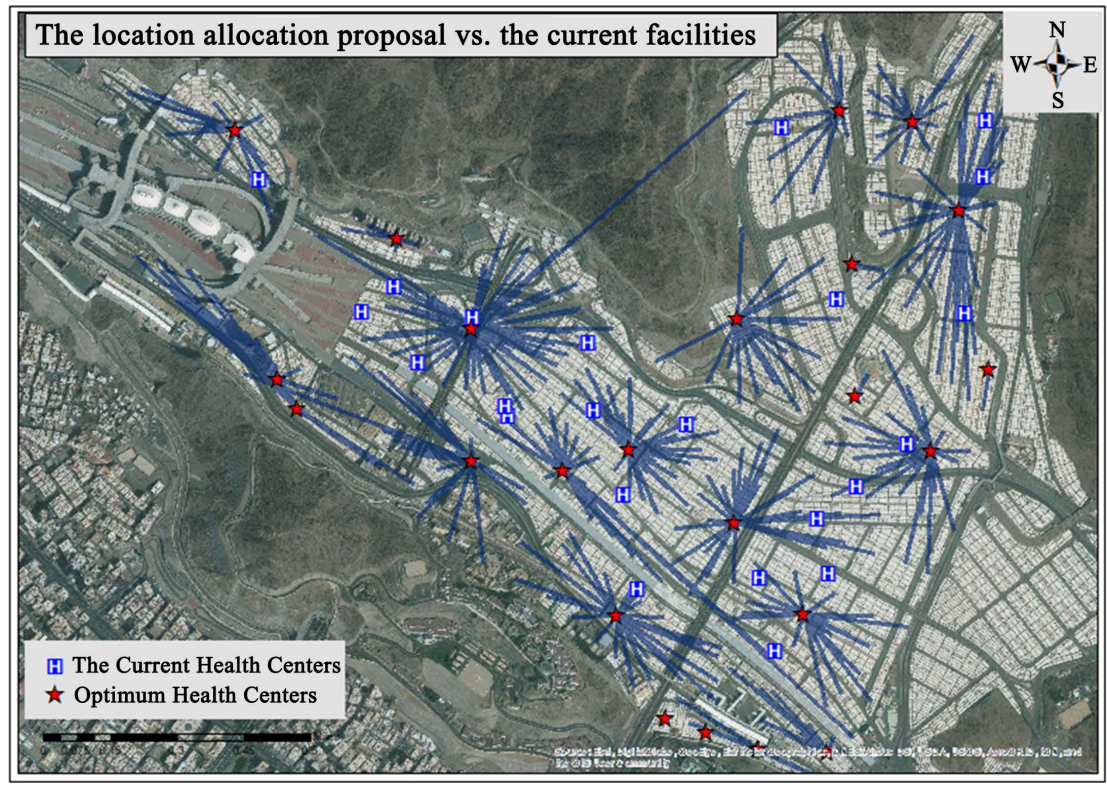

Figure 7. Optimal versus current locations of health centres.

Table 4. Numbers of pilgrims in different accessibility bands for current and optimal health centre locations.

\begin{tabular}{ccc}
\hline Distance & POP/current health centres & POP/optimum health centres \\
\hline $\mathbf{0}-\mathbf{1 5 0} \mathrm{m}$ & 210,081 & 275,917 \\
$\mathbf{1 5 0}-\mathbf{3 0 0 \mathrm { m }}$ & 516,389 & 840,388 \\
$\mathbf{3 0 0}-\mathbf{4 5 0} \mathrm{m}$ & 705,765 & 670,304 \\
$\mathbf{4 5 0}-\mathbf{6 0 0 \mathrm { m }}$ & 479,958 & 423,763 \\
$\mathbf{6 0 0}-\mathbf{7 5 0} \mathrm{m}$ & 175,660 & 192,470 \\
$\mathbf{7 5 0}-\mathbf{9 0 0} \mathrm{m}$ & 231,183 & 68,543 \\
$\mathbf{9 0 0} \mathbf{m}+$ & 170,379 & 18,030 \\
total & $2,489,415$ & $2,489,415$ \\
\hline
\end{tabular}


of persons now in the low accessibility bands for the optimal 23 locations but also the reduction of numbers in the higher brackets too. Thus we now see a significant increase in the numbers of people falling within $500 \mathrm{~m}$ of a health centre and many fewer in the $750 \mathrm{~m}$ plus. The optimal solutions include six new centres in the previously uncovered demand areas along the north and south-west edges of Mina, producing a significant increase in access for the workers at the Hajj as well as the pilgrims.

Figure 8 shows the current distribution of the 43 civil defence centres alongside the optimal results from the LAM. As can be seen, the distribution of current civil defence centres covers the centre of Mina well and also provides good coverage around the bridge where accidents are most likely to occur. The optimal solutions also, as with the health centres, provides better coverage to the more peripheral areas, especially in this case to the north.

Table 5 shows the present accessibility levels and the change for the optimal centres for civil defence. Again more people now fall into the lower categories

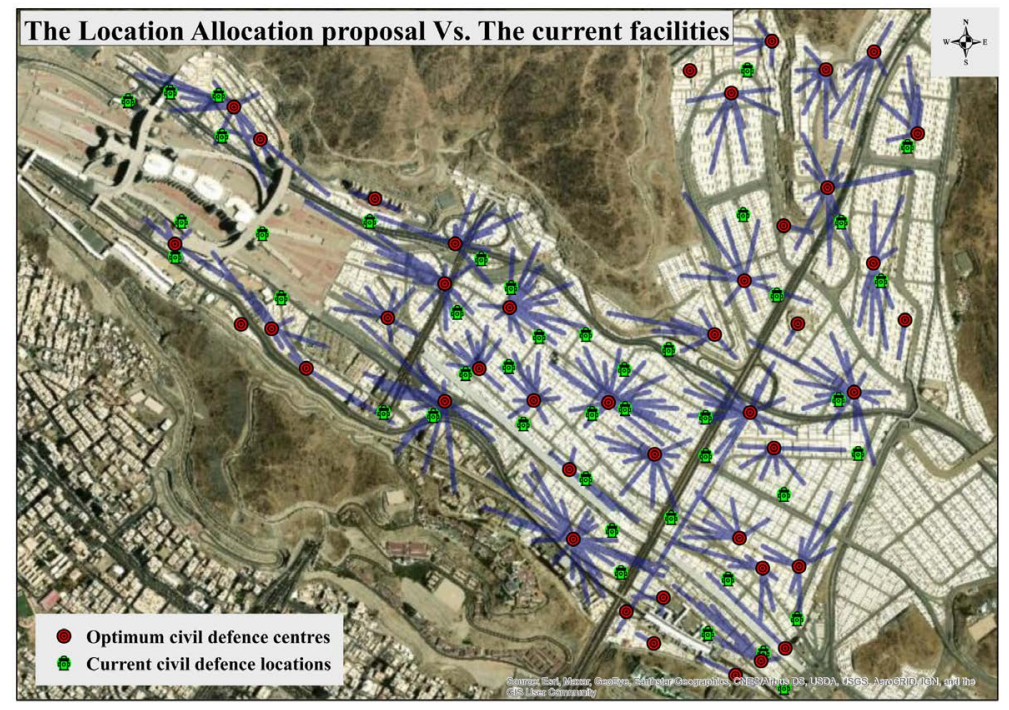

Figure 8. Optimal versus current locations of civil defence centres.

Table 5. Numbers of pilgrims in different accessibility bands for current and optimal civil defense centre locations.

\begin{tabular}{cccc}
\hline Distance & $\begin{array}{c}\text { the number of population } \\
\text { served by current } \\
\text { civil defence }\end{array}$ & $\begin{array}{c}\text { the number of population } \\
\text { served by optimum } \\
\text { civil defence }\end{array}$ & $\begin{array}{c}\% \\
\text { change }\end{array}$ \\
\hline $\mathbf{0}-\mathbf{1 5 0} \mathrm{m}$ & 316,858 & 422,561 & 33.35974 \\
$\mathbf{1 5 0}-\mathbf{3 0 0 \mathrm { m }}$ & 688,048 & 770,048 & 11.91777 \\
$\mathbf{3 0 0}-\mathbf{4 5 0} \mathrm{m}$ & 510,906 & 605,403 & 18.49597 \\
$\mathbf{4 5 0}-\mathbf{6 0 0} \mathrm{m}$ & 563,961 & 501,590 & -11.0595 \\
$\mathbf{6 0 0}-\mathbf{7 5 0} \mathrm{m}$ & 260,630 & 154,524 & -40.7114 \\
$\mathbf{7 5 0}-\mathbf{9 0 0} \mathrm{m}$ & 111,915 & 26,271 & -76.5259 \\
$\mathbf{9 0 0} \mathbf{m}+$ & 37,097 & 9018 & -75.6908 \\
total & $2,489,415$ & $2,489,415$ & 0 \\
\hline
\end{tabular}


(thus more people are having to travel less far) and less people are having longer distance trips.

In both of the above examples the optimal centres provide a much better and more equitable coverage for the residents whilst they are in Mina. This includes the pilgrims and the workers. Access times are considerable reduced for the population as a whole, although of course some residents would have their journey times increased if a local centre was redistributed in this fashion.

\section{Planning for Change: What-If Scenarios}

In this section we look at 2 scenarios for change as an illustration of the usefulness of the LAMs In the first example we introduce an applied scenario around reducing costs. In the second scenario we use the LAMs to explore service provision by time of day. This introduces an element of dynamics not often considered in LAMs.

\subsection{Reducing Costs}

As noted in the introduction, the Saudi Government is keen to reduce costs at the Hajj in the future. The first scenario we model here is a reduction in the number of facilities in order to reduce costs. For illustration we focus only on health centres. In this scenario (see Figure 9), the model is run for 20 and then 15 centres rather than the existing 23 centres. Both scenarios would obviously reduce costs significantly. Figure 9 shows the three health centres which are removed by the model in the 20 centre solution. All 3 are located in close proximity to the Jamarat Bridge, especially in the immediate eastern areas. Figure 10 shows the results for the 15 centre solution. Here the closures are more widespread across the city. Table 6 shows the impact on accessibility with the reduced number of centres. Not surprisingly, as the number of centres is

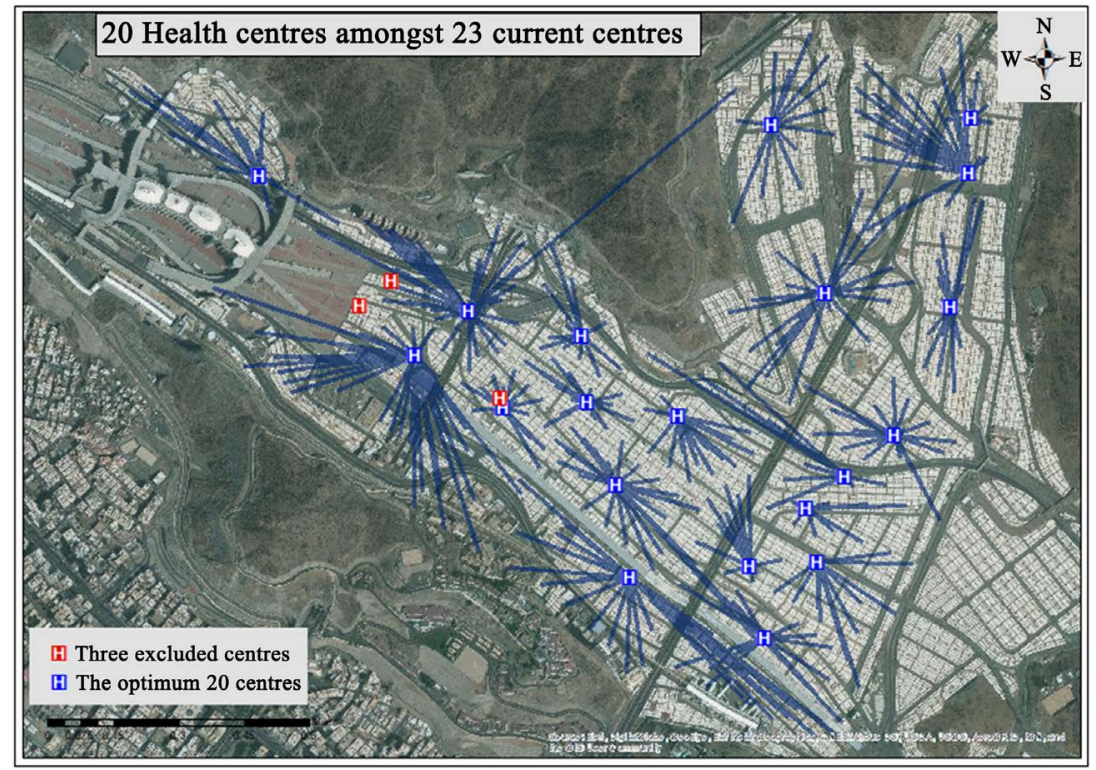

Figure 9. Optimal locations for 20 health centres. 


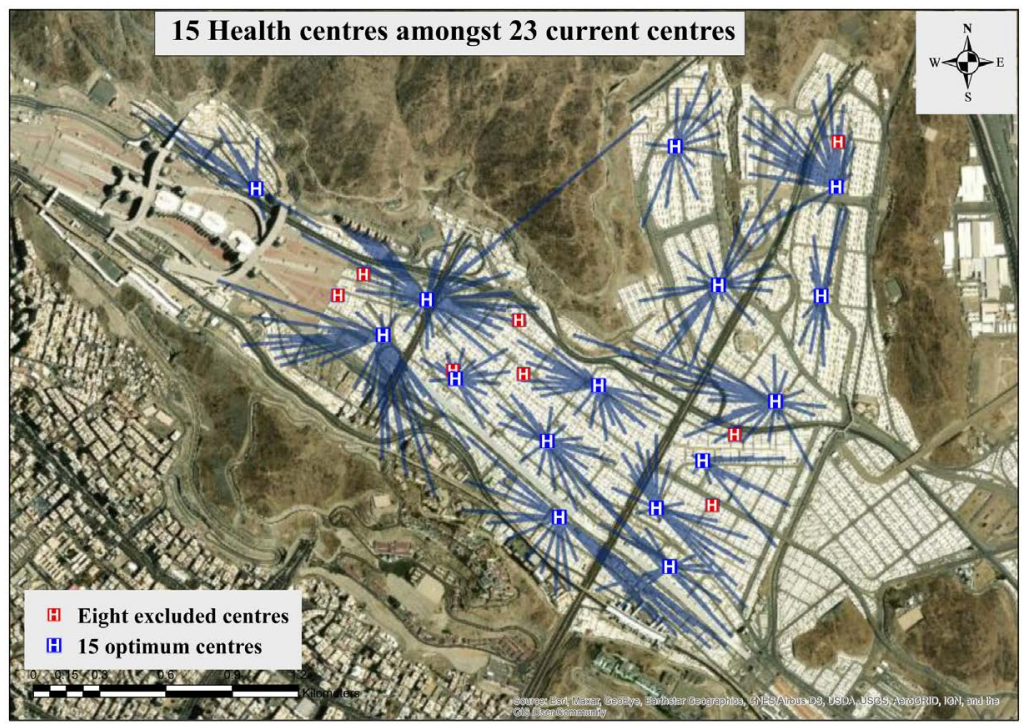

Figure 10. Optimal location of 15 health centres.

Table 6. Population within access bands for different cost saving scenarios.

\begin{tabular}{ccccc}
\hline Distance & pop/current & pop/23 opt & pop/20 opt & pop/15 opt \\
\hline $\mathbf{0}-\mathbf{1 5 0} \mathrm{m}$ & 210,081 & 275,917 & 207,086 & 131,042 \\
$\mathbf{1 5 0}-\mathbf{3 0 0 ~ \mathrm { m }}$ & 516,389 & 840,388 & 770,728 & 533,471 \\
$\mathbf{3 0 0}-\mathbf{4 5 0} \mathrm{m}$ & 705,765 & 670,304 & 672,645 & 664,413 \\
$\mathbf{4 5 0}-\mathbf{6 0 0} \mathrm{m}$ & 479,958 & 423,763 & 504,080 & 560,992 \\
$\mathbf{6 0 0}-\mathbf{7 5 0} \mathrm{m}$ & 175,660 & 192,470 & 217,848 & 335,485 \\
$\mathbf{7 5 0}-\mathbf{9 0 0} \mathrm{m}$ & 231,183 & 68,543 & 88,245 & 194,327 \\
$\mathbf{9 0 0} \mathbf{m}+$ & 170,379 & 18,030 & 28,783 & 69,685 \\
total & $2,489,415$ & $2,489,415$ & $2,489,415$ & $2,489,415$ \\
\hline
\end{tabular}

reduced so overall access becomes poorer. Although these scenarios would save costs, many of the suggested closures occur in areas on the direct routes of the pilgrims making their way to the Bridge. In very hot weather this movement causes weariness and many potential health issues. If cost cutting was deemed to be necessary then maybe some hybrid of these solutions would be good-to close the more peripheral centres suggested in the 15 centre scenario whilst keeping the cluster of centres near the bridge. This idea is progressed as we move into the second scenario.

\subsection{Locating Services Based on Daily Population Movements}

Little work has been done on short-term temporal changes within LAM. Othman (2003) proposed a system of Mobile Service Units (MSUs) at the Hajj but not from an optimal location perspective. To explore this scenario we first need to estimate the population across Mina at different times of the day. This follows the movement of the pilgrims as they leave their tents and move to the Bridge and back. Figure 11 shows a likely distribution of the population of Mina around midday. We estimate that typically at midday $70 \%$ of the pilgrim popula- 
tion of Mina is expected to be around the Bridge area at the middle of the day and early afternoon (an increase of $178 \%$ from the night-time population). These will be mainly located around the pathways to the Bridge. The middle zone now contains just $20 \%$ of the population, with many of that $20 \%$ about to follow the other pilgrims to the bridge. The final outer zone has just $10 \%$ of the population at this time of the day.

Figure 12 shows the LAM results using this new population distribution in comparison with the results for the resident tented population. Naturally, the model now allocates many more centres within the vicinity of the Bridge. In reality it would not be easy to switch between the two systems of provision but it would probably be relatively easy to transfer medical staff (rather than equipment) during the day. Figure 13 repeats the analysis for the civil defence services.

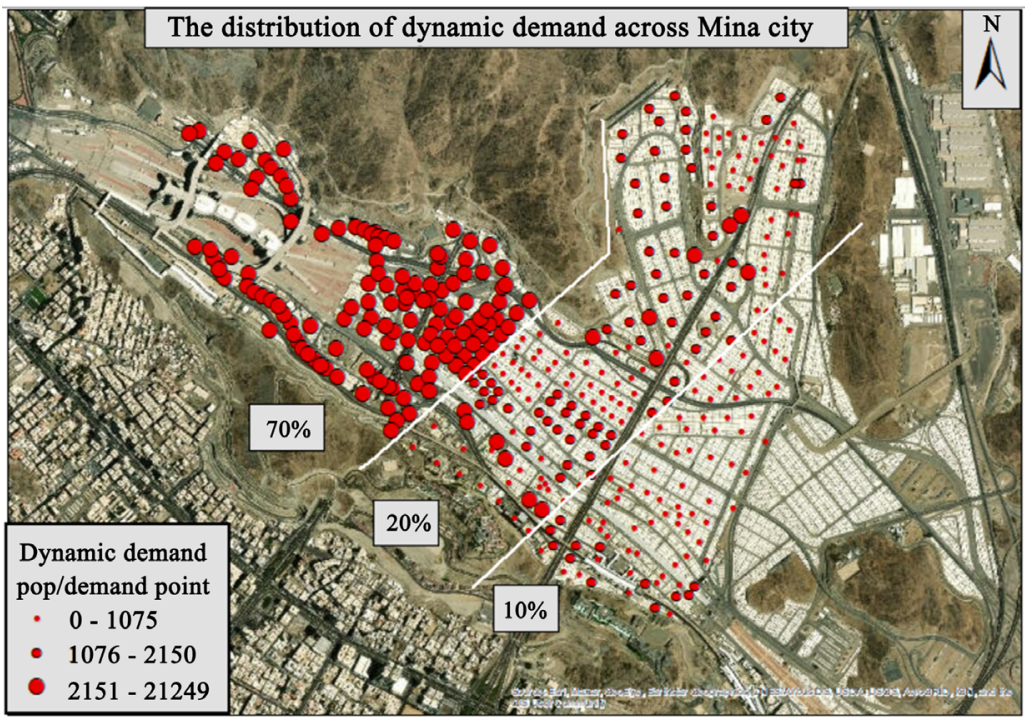

Figure 11. The distribution of dynamic demand across mina by population.

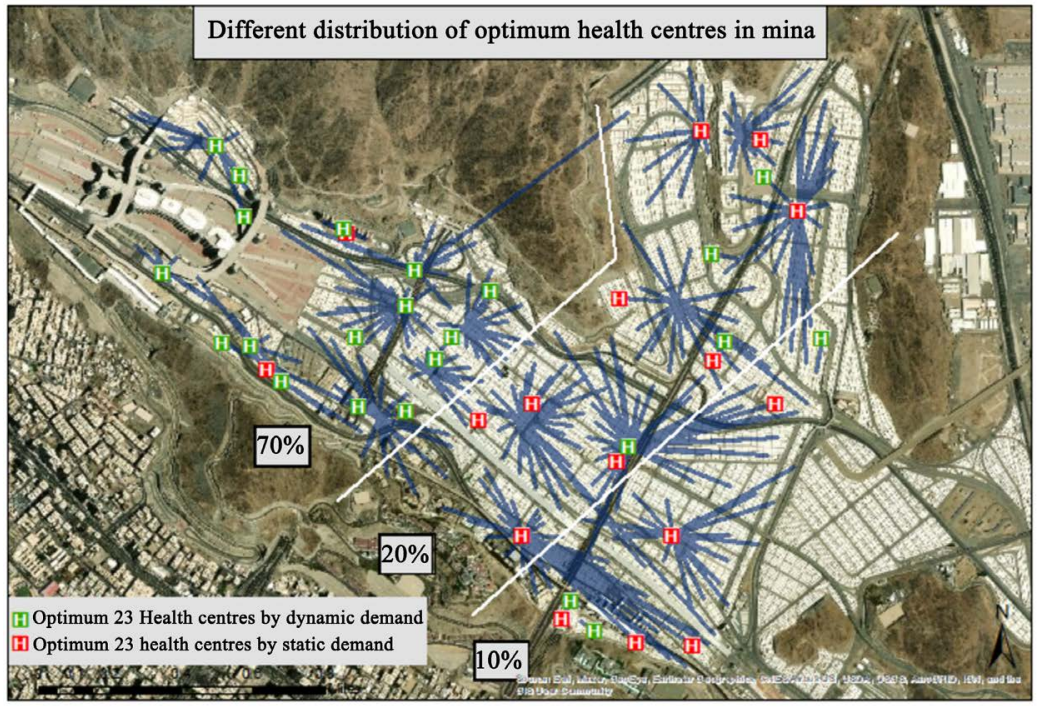

Figure 12. Optimal for midnight vs. optimal centres for midday in mina. 


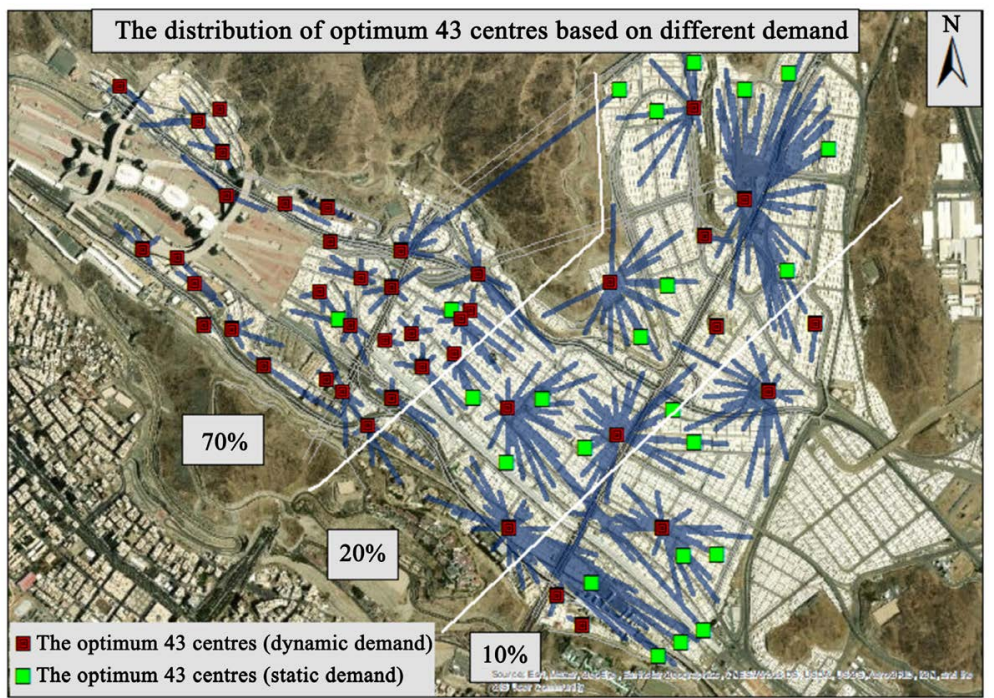

Figure 13. The optimal location of civil defence centres at midday vs. midnight in mina.

Once again a much more concentrated pattern of services would be available to the pilgrims as they undergo the most dangerous part of the pilgrimage- the mass movement of people to and from the Bridge.

\section{Discussion}

Service provision is a very important issue for decision makers especially for an international event such as the Hajj. For a few weeks the eyes of the world are on the Saudi authorities and any major incidents are reported globally. Health and civil defence centres have been chosen in this study because of their importance in ensuring the safety and well-being of the many millions of visitors. Planning services is always a compromise between efficiency (good use of scare resources) and effectiveness (the ability to operate these services with a degree of equity in access). The results of the location-allocation model show that it is possible to distribute services more efficiently and effectively, certainly in comparison to the current distribution of facilities. In no situation have we increased the number of services. However we have shown how solutions can be obtained which allow far more pilgrims a service coverage within $300 \mathrm{~m}$ of their night-time locations and also, through the dynamic analysis of demand movements, through the daytime as well. This has been shown to be the case even when we reduce the number of service locations across the Hajj. With a reduced set of facilities it is still possible to improve the accessibility of pilgrims compared to the present set of facility locations.

The results of our analysis undoubtedly have major positive implications for costs. Although the Saudi Government earns a substantial income from the Hajj (most importantly through taxation of accommodation) it also has to bear the costs of service provision. For example, health care is provided free of charge at the point of usage during the event. Thus any savings made in relation to the number of centres and staffing must be welcomed, especially if the savings can 
be used to help reduce the cost of attending the Hajj which have increased at a rate of over 25\% per annum over the last few years. Even back in 2010 the BBC reported that concern was being increasingly aired that the Hajj had become "a rich person's privilege" (BBC, 2010). The results of the location-allocation modelling could also help revamp staffing rotas-not only can the model provide optimal locations they can estimate the workloads associated with each facility location (based on the volume of local demand), meaning the thousands of health workers could be also located more optimally. The results of the daytime modelling would be especially useful here: for example, staff could be transferred during the day from Muzdalifah or Arafat to support the greater demand expected to be near the Jamarat Bridge.

In this paper we have focused on health and emergency services. However, the models could easily be applied to other services such as food outlets, water supply and information centres. In addition it would be possible to disaggregate the analysis within the two categories we have explored in this paper. For example it would be useful to split health care by type of care: emergency facilities, health centres and "cooling" units to cater for heat exhaustion and sunstroke (Eltahir, 2000). Future work could also involve the disaggregation of the demand surface we have used for the location-allocation models. Age is a key explanatory variable for hospital admissions at the Hajj (Al-Ghamdi et al., 2003) and this could be incorporated into future analyses (along with ethnicity and perhaps social class-estimated via the variations seen in accommodation prices set across the tented city of Mina).

One of the limitations of this research is that the daytime populations used in the dynamic LAMS are based on estimates only. It is difficult to estimate the real number moving in the pathways/streets which in turn may influence the accuracy of the results. Hence future work could also attempt to survey and count people while they are moving around the site to create more accurate estimates of their locations at times other than night time. More broadly, given the potential for modelling the various day-time locations of the pilgrims and their numbers, it would be interesting in future research to link individual movements in the city more closely with service provision and location. This could be achieved by modelling crowd behaviour and location in more detail (especially along the road and pathways in the city) in order to obtain more precise detail on the location of pilgrims at different times of the day. Crowd modelling is now well-established in the literature (Hughes, 2003; Torrens et al., 2012; Sharma et al., 2016) and there have even been a few preliminary studies on crowd movements within the Hajj using agent-based models (Al-Kodmany, 2013; Ilyas, 2013; Tayan et al., 2014). Building on these studies would enable us to build more accurate estimations of crowd movements within the Hajj which would, in turn, dovetail well with further attempts to optimise service provision.

\section{Conclusion}

Temporary cities provide huge logistical problems for planners and policy mak- 
ers alike. The welfare of citizens is paramount and it is important to consider the most accessible locations of key services such as health, water, emergency assistance and fire services. In this paper, we have explored the optimal provision of health and emergency service locations in comparison to the existing set of facilities for the pilgrim city of Hajj. It has been shown how accessibility can be improved considerably when such optimisation models are used. We have also showed how scenarios for change can be evaluated in order to facilitate better future planning decisions. The illustrations presented here showed scenarios based first around cost cutting and the removal of key services. If costs are to be reduced it is important that consumer access is not compromised. Hence, consideration of optimal locations becomes even more important. Second, we explored how location models could be used for an evaluation of service provision at different times of the day. This has rarely been undertaken in the literature on location models to date.

\section{Conflicts of Interest}

The authors declare no conflicts of interest regarding the publication of this paper.

\section{References}

Ahmed, Q. A., Arabi, Y. M., \& Memish, Z. A. (2006). Health Risks at the Hajj. The Lancet, 367, 1008-1015. https://doi.org/10.1016/S0140-6736(06)68429-8

Al-Ghamdi, S. M., Akbar, H. O., Qari, Y. A., Fathaldin, O. A., \& Al-Rashed, R. S. (2003). Pattern of Admission to Hospitals during Muslim Pilgrimage (Hajj). Saudi Medical Journal, 24, 1073-1076.

Alharthi, N., \& Gutub, A. (2017). Data Visualization to Explore Improving DecisionMaking within Hajj Services. Scientific Modelling and Research, 2, 9-18. https://doi.org/10.20448/808.2.1.9.18

Al-Kodmany, K. (2009). Planning for the Hajj: Political Power, Pragmatism, and Participatory GIS. Journal of Urban Technology, 16, 5-45. https://doi.org/10.1080/10630730903090289

Al-Kodmany, K. (2013). Crowd Management and Urban Design: New Scientific Approaches. Urban Design International, 18, 282-295. https://doi.org/10.1057/udi.2013.7

BBC (1998). Saudis Identifying Nationalities of 118 Dead Pilgrims.

BBC (2001). Lessons from Hajj Deaths.

BBC (2007). History of Deaths on the Hajj.

BBC (2010). Are British Muslims Being Priced Out of Pilgrimages?

Bozonelos, D. (2015). Pilgrimage Experience and Consumption of Travel to the City of Makkah for Hajj Ritual. International Journal of Religious Tourism and Pilgrimage, 3,

Chen, L., Peng, J., Zhang, B., \& Li, S. G. (2017). Uncertain Programming Model for Uncertain Minimum Weight Vertex Covering Problem. Journal of Intelligent Manufacturing, 28, 625-632. https://doi.org/10.1007/s10845-014-1009-1

Colomb, C. (2012). Pushing the Urban Frontier: Temporary Uses of Space, City Marketing, and the Creative City Discourse in 2000s Berlin. Journal of Urban Affairs, 34, 131 152. https://doi.org/10.1111/j.1467-9906.2012.00607.x 
Eltahir, A. H. H. (2000). Development of Health Services in Hajj Seasons. Journal of Family \& Community Medicine, 7, 13-14.

Farahani, R. Z., Asgari, N., Heidari, N., Hosseininia, M., \& Goh, M. (2012). Covering Problems in Facility Location: A Review. Computers \& Industrial Engineering, 62, 368407. https://doi.org/10.1016/j.cie.2011.08.020

Fayoumi, A., Al-Ghoraibi, S., Fadel, A., Al-Aswadi, F., Mujallid, F., \& Wazzan, M. (2011). A Simulator to Improve the Pilgrims Performance in Stoning Ritual in Hajj. International Journal of Computer Science Network Security, 11, 141-144.

Ferreri, M. (2015). The Seductions of Temporary Urbanism. Ephemera, 15, 181.

Garner, J. (1992). The Company Town: Architecture and Society in the Early Industrial Age. Oxford: Oxford University Press.

Goodchild, M. F. (1984). ILACS: A Location-Allocation Model for Retail Site Selection. Journal of Retailing, 60, 84.

Haase, K., Kasper, M., Koch, M., \& Müller, S. (2018). A Pilgrim Scheduling Approach to Increase Safety during the Hajj. Operations Research, 67, 376-406. https://doi.org/10.1287/opre.2018.1798

Halabi, W. (2012). Analysis of Activities and Movement Patterns of Worshippers' at the Western Piazza of the Holy Mosque, Makkah, Saudi Arabia. The Institute of the Custodian of the Two Holy Mosques for Hajj Research.

Haydn, F., \& Temel, R. (2006). Temporary Urban Spaces: Concepts for the Use of City Spaces. Basel: Birkhäuser.

Herring, C., \& Lutz, M. J. C. (2015). The Roots and Implications of the USA's Homeless Tent Cities. City, 19, 689-701. https://doi.org/10.1080/13604813.2015.1071114

Hodgson, M. J. (1978). Toward More Realistic Allocation in Location-Allocation Models: An Interaction Approach. Environment and Planning A: Economy and Space, 10, 1273-1285. https://doi.org/10.1068/a101273

Houdart, S. (2012). A City without Citizens: The 2010 Shanghai World Expo as a Temporary City. City, Culture and Society, 3, 127-134.

https://doi.org/10.1016/j.ccs.2011.11.005

Hughes, R. L. (2003). The Flow of Human Crowds. Annual Review of Fluid Mechanics, 35, 169-182. https://doi.org/10.1146/annurev.fluid.35.101101.161136

Ilyas, Q. M. (2013). A Netlogo Model for Ramy Al-Jamarat in Hajj. Journal of Basic and Applied Scientific Research, 3, 199-209.

Kar, B., \& Hodgson, M. E. (2008). A GIS-Based Model to Determine Site Suitability of Emergency Evacuation Shelters. Transactions in GIS, 12, 227-248. https://doi.org/10.1111/j.1467-9671.2008.01097.x

Keane, J. A., \& Ward, T. A. (2002). A Computational Framework for Location Analysis. IEEE Transactions on Systems, Man, and Cybernetics Part A: Systems and Humans, 32, 574-581. https://doi.org/10.1109/TSMCA.2002.804819

King, R. (1972). The Pilgrimage to Mecca: Some Geographical and Historical Aspects. Erdkunde, 26, 61-73. https://doi.org/10.3112/erdkunde.1972.01.06

Koshak, N. (2006). Developing a Web-Based GIS for Hajj Traffic Plan (HajjGIS.Net). Journal of Urban Planning Research, Cairo University, 6, 1-13.

Loftus-Farren, Z. (2011). Tent Cities: An Interim Solution to Homelessness and Affordable Housing Shortages in the United States. California Law Review, 99, 1037-1081.

Madanipour, A. (2018). Temporary Use of Space: Urban Processes between Flexibility, Opportunity and Precarity. Urban Studies, 55, 1093-1110. 
https://doi.org/10.1177/0042098017705546

Mady, C. (2012). Diversity in Conviviality: Beirut's Temporary Public Spaces. Open House International, 37, 63-71.

Marianov, V., \& de la Figuera, D. S. (2004). New Trends in Public Facility Location Modelling. Barcelona: Universitat Pompeu Fabra.

Mitchell, R. O. et al. (2013). Hajj Crowd Management and Navigation System: People Tracking and Location Based Services via Integrated Mobile and RFID Systems. In 2013 International Conference on Computer Applications Technology. https://doi.org/10.1109/ICCAT.2013.6522008

Montgomery, J. (1998). Making a City: Urbanity, Vitality and Urban Design. Journal of Urban Design, 3, 93-116. https://doi.org/10.1080/13574809808724418

Othman, F. M. (2003). A System of Mobile Service Units for the Large-Scale Event Industry: An Implementation for the Hajj, the Pilgrimage to Makkah, Saudi Arabia.

Peters, F. E. (1996). The Hajj: The Muslim Pilgrimage to Mecca and the Holy Places. Princeton, NJ: Princeton University Press.

Rahman, S.-U., \& Smith, D. K. (2000). Use of Location-Allocation Models in Health Service Development Planning in Developing Nations. Amsterdam: Elsevier. https://doi.org/10.1016/S0377-2217(99)00289-1

Sharma, D., Bhondekar, A. P., Shukla, A. K., \& Ghanshyam, C. (2016). A Review on Technological Advancements in Crowd Management. Journal of Ambient Intelligence and Humanized Computing, 1-11. https://doi.org/10.1007/s12652-016-0432-x

Sparks, T. J. U. G. (2017). Neutralizing Homelessness, 2015: Tent Cities and Ten Year Plans. Urban Geography, 38, 348-356. https://doi.org/10.1080/02723638.2016.1247600

Tayan, O., Al BinAli, A. M., \& Kabir, M. N. (2014). Analytical and Computer Modelling of Transportation Systems for Traffic Bottleneck Resolution: A Hajj Case Study. Arabian Journal for Science and Engineering, 39, 7013-7037. https://doi.org/10.1007/s13369-014-1231-3

Toregas, C., Swain, R., ReVelle, C., \& Bergman, L. (1971). The Location of Emergency Service Facilities. Operations Research, 19, 1363-1373. https://doi.org/10.1287/opre.19.6.1363

Torrens, P. M., Nara, A., Li, X., Zhu, H., Griffin, W. A., \& Brown, S. B. (2012). An Extensible Simulation Environment and Movement Metrics for Testing Walking Behavior in Agent-Based Models. Computers, Environment and Urban Systems, 36, 1-17. https://doi.org/10.1016/j.compenvurbsys.2011.07.005

Vision, K. (2019). Document of Rahaman Guests Serving Program. 